\title{
Information Communication Technology Diffusion for Rural Development
}

\author{
Dr. K. Lokeswari* \\ Assistant Professor, Department of Communication, PSG College of Arts and Science, Coimbatore.
}

\begin{abstract}
Information and Communication Technology (ICT), has changed the way people learn, live, interact and work. Information Technology (IT) has also created divide in the digital society among "haves" and "havenots" in the technology access and the ability to use ICT among rural. There is a vast impact of ICT on the rural areas and rural lives. The paper investigates extent of ICT diffusion and digital divide across the selected Indian states. Various determinants of Digital Divide and ICT diffusion have been discussed. The paper also discusses the initiatives of bridging the digital divide in rural development and implications for rural development.
\end{abstract}

Keywords: ICT, Diffusion, Rural Development

\section{INTRODUCTION}

Information and Communication Technology (ICT) revolution have evolved dramatically in transforming societies, cultures and economies. The application of Information Technology (IT) in various fields and Internet technology has been able to influence larger sections of society. ICT includes any communication applications or devices that encompasses of television, radio, cellular phones, computer and network software and hardware, satellite systems etc., as well as the many other services and applications related with them, such as videoconferencing and distance learning. ICT diffusion refers to the persuaded IT development, which increases productivity, competitiveness, economic growth and human welfare from the use of technology by different sectors of economy (Saundarjya, 2005) and there begins the digital divide in the use, access, skills and others. There seems to be an inequality between "haves" and "have-nots". When information technology became popular, debates on the impact of this technology were midpoint on 'information gaps' between the developed and developing countries. This awareness gave birth to another term the 'digital divide' 'in 1990s which encompasses broader meaning than information gap (Fong, 2009). In this context, the role of ICTs plays a significant role in rural, national development and to achieve the universal access of ICTs. The Digital Divide is a social issue denoting to the contradictory amount of information between those who have access to the Internet and those who do not have access. The term became popular among scholars, policy makers, and advocacy groups, in the late 1990. The ease of access of rural areas to the Internet is a test of the digital divide. But currently there are diverse ways to eradicate the digital divide in rural areas. Use of Power lines and satellite communications proposal has new possibilities of universal access to the Internet, and lack of telephone lines will not limit access. Incapability of potential Internet users constitutes another type of divide and maintenance should be taken to avoid that persons with disabilities be left out of Internet access. Rural development is the process of improving the quality of life and economic well being of people living in relatively isolated and sparsely populated areas. The people of India live mostly in rural areas (villages). Therefore, it is the heart of the villages that the nation lives. The well being of India depends upon the prosperity of the villages. The main focus of this paper is on the bridging the digital divide between rural areas per population. The main focus of this paper is on the bridging the digital divide between rural areas per population.

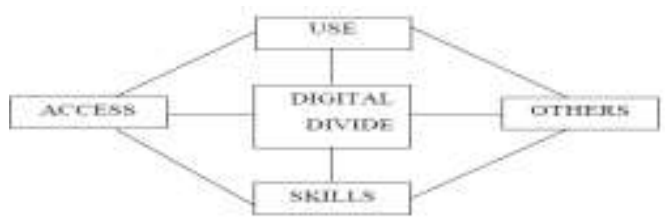

Figure1. Conceptual Framework of Digital Divide 


\section{REVIEW OF LITERATURE}

Baliamoune-Lutz and Mina, (2003), "An analysis of the determinants and effects of ICT diffusion in developing countries" observes the associations among ICT diffusion and per capita income, trade and financial indicators, education, and freedom indicators. Internet hosts, Internet users, personal computers and mobile phones represent indicators of ICT. The outcomes show that income and government trade policies influence ICT diffusion. However, freedom indices may or may not affect ICT diffusion. Moreover, only personal computers and Internet hosts seem to have a positive association with income. Contrary to expectations, ICT diffusion is not associated with education. ${ }^{1}$

Poh-Kam Wong,(2002), "ICT production and diffusion in Asia Digital dividends or digital divide?" examines the observed indication to determine whether Asian countries, although having captured a excessively high share of global production of ICT goods, have as a group been straggler in the adoption of ICT in evaluation to non-Asian countries. Using regression analysis, it is exposed that as a group Asian countries have indeed had generally lower rates of ICT adoption qualified to their levels of potential as predicted on the basis of their current level of development (GDP/capita) and competitiveness (world competitiveness index). In addition, inequalities in ICT diffusion are examined to be significantly higher among Asian countries than among non-Asian countries. In specific, a significant 'digital divide' is found to exist between the five more progressive countries of the region (Japan and the four Asian NIEs) and the other seven developing Asian countries. Policy implications of the findings for the Asian countries are highlighted. ${ }^{2}$

SeifallahSassia and Mohamed Goaieda, (2013), "Financial development, ICT diffusion and economic growth: Lessons from MENA region" investigates the interaction between financial development and ICT Diffusion to test whether the impact of financial development on growth is strengthened by better ICT infrastructure. Finally, the interaction between ICT penetration and financial development is examined to be positive and significant in the growth regression. This implies that economies in Mena region can benefit from financial development only once a threshold of ICT development is reached. ${ }^{3}$

Jan van Dijk and Kenneth Hacker, (2003), "The Digital Divide as a Complex and Dynamic Phenomenon" study shows that differential access of skills and usage is likely to increase. The growth of a usage gap is projected. The usage gap is related to the evolution of the information and network society. Finally, they have discussed policy perspectives. ${ }^{4}$

Anand Chopra, "Bridging India's Digital Divide: Some Policy and Technological Options" tests and explains two hypotheses, one stating that by removing government monopoly, liberalizing and delicensing the telecom sector would help the brisk dissemination of ICT in rural areas and the other stating that by the coordination of stakeholders like government, industry, civil society and community in establishing Internet kiosks to villages would help the brisk dissemination of ICT in rural areas and found that both the hypotheses are strongly supported as a result of the analysis of these interviews. ${ }^{5}$

Nair Prema P and Mathiyalagan N, (2008), "Revamping organizations through ICT rat race at workplace", examined into the computer usage pattern and intensity, to deliberate on issues that go beyond describing the digital divide to analyzing digital inequality from Coimbatore, a district in Tamil Nadu. ${ }^{6}$

Simone Cecchini and Christopher Scott, (2003), "Can information and communications technology applications contribute to poverty reduction? Lessons from rural India", explains that the Information and Communications Technology (ICT) can decrease poverty by improving poor people's access to education, health, government and financial. It is flawless that in rural India as well as in much of the developing world- realization of this potential is not guaranteed. This paper sketches a simple model to explain why a digital divide may exist between rich and poor. Low-cost access to information

\footnotetext{
${ }^{1}$ http://content.iospress.com/articles/information-technology-for-development/itd00093

${ }^{2}$ http://www.sciencedirect.com/science/article/pii/S0167624501000658

${ }^{3}$ http://www.sciencedirect.com/science/article/pii/S0308596112002054

${ }^{4}$ http://www.tandfonline.com/doi/abs/10.1080/01972240309487

${ }^{5}$ https://www.uni-hohenheim.de/wi-theorie/globalisierung/dokumente/chopra_wp.pdf

${ }^{6} \mathrm{http}: / / \mathrm{www}$. indianjournals.com/ijor.aspx?target $=$ ijor:mcomm $\&$ volume $=2 \&$ issue $=1 \&$ article $=002$
} 
infrastructure is a necessary precondition for the successful use of ICT by the poor, but it is not sufficient. ${ }^{7}$

Best, Michael L .and Kumar, Rajendra, (2008), "Sustainability Failures of Rural Telecenters: Challenges from the Sustainable Access in Rural India (SARI)", examined longitudinally an ICT for a development project in rural India, closely watching activities and surveying users at as many as 100 Internet facilities in more than 50 different villages. The Sustainable Access in Rural India (SARI) project in Tamil Nadu, India, enjoyed many successes. Finally, telecenters that were owned by individuals with prior training in computers, or that had a separate trained operator, remained operational for a longer period. ${ }^{8}$

Christopher Blattman, Robert Jensen \& Raul Roman(2002), "Assessing the Need and Potential of Community Networking for Development in Rural India", explains the results and conclusions of a mixed-methods research strategy designed to evaluate the potential of community networking in rural Tamil Nadu, India. The article determines by stating the importance of basic communication technologies and contextually relevant information services, and suggesting recommendations for future research in this area. ${ }^{9}$

\section{CONCEPT}

\subsection{ICT and ICT Diffusion:}

The OECD (Organization for Economic Cooperation and Development) Growth Study concluded that information and communications technology (ICT) is a key input to productivity and growth performance. This sequence of peer analyses on ICT diffusion to business, undertaken by the Working Party on the Information Economy, responds to the OECD Council Ministerial request for the OECD to increase its monitoring of member countries' implementation of the Growth Study recommendations. 10

\subsection{Digital Divide:}

According to Organization for Economic Cooperation and Development (OECD)(2001) the term digital divide refers to "the gap between individuals, households, businesses and geographic areas at the different socioeconomic levels with regard to their opportunities to access information and communication technologies (ICT) and their use of internet".

According to Bernardo Sorj, "The digital divide depends on five factors that determine the level of equality of access to information technology systems:

- The existence of physical infrastructure for transmission;

- The availability of connection equipment such as a computer, modem, and access line;

- Training in the use of the computers and the Internet;

- Intellectual capacities and the social insertion of users (this is the product of the educational and intellectual level, profession and the social network that determines the effective use of information and the necessities of Internet communication

- The production and use of specific contents adapted to the needs of the diverse segments of the population. While first the two criteria refer to passive dimensions of Internet access, the last three dimensions define areas of potential active appropriation."

\subsection{Rural Development:}

Rural Development refers to process of improving or uplifting the living conditions of the people living in rural areas. The ways and means of rural development:

- Education of the masses

\footnotetext{
${ }^{7}$ http://onlinelibrary.wiley.com/doi/10.1002/itdj.1590100203/full

${ }^{8}$ http://itidjournal.org/itid/article/view/309

${ }^{9}$ https://pdfs.semanticscholar.org/6dcb/3e88003fbcf33ace05bee5e33b6297d39f5d.pdf

${ }^{10} \mathrm{http} / / / \mathrm{www}$. oecd.org/sti/ieconomy/ictdiffusiontobusinessnationalpeerreviews.htm
} 
- Establishment of night schools for adults

- Improvement of sanitation

- Provisions for cheap medical aid

- Construction of good roads

- Establishment of co-operative credit societies

\section{Digital Divide IN INDIA}

In the 1990s government as well as the organizations in the world became concerned about the inequality in the access to new technologies, whether among individuals or in the institution, labeling this inequality in the access a digital divide helped draw attention to the issue. In that sense there is not one Digital divide but many, and diverse efforts on many fronts are needed to overcome them. (Warschauer.M, 2010). The digital divides is continual and still with us but public library are making difference. The strong positive response from both consumers and librarians combined with the clear important of technology literacy in to-days world, justifies continued investment and support in public access computer and library in fracture necessary to support then. If we are really enthusiastic to serve in the digital information revolution, there is no full stop to serve opportunities if we do not want to effectively serve, the service will not stop. We needed to develop models of collaboration among researchers, social scientists, librarian's technologists etc. So that local requirements are met in a technology innovation. Since India's heart lies in its villages, rural library can plays a much-needed role not only in bridging digital divide but also in building a well-informed and literate society.

Table1. Top 10 Countries with highest number of Internet Users - June 30, 2016

\begin{tabular}{|c|c|c|c|c|c|c|}
\hline \multirow{2}{*}{$\#$} & \multirow{2}{*}{ Country or Region } & Population, & Internet Users & Internet & Growth (*) & Facebook \\
\cline { 3 - 7 } & & $\mathbf{2 0 1 6}$ Est. & 30-Jun-16 & Penetration & $\mathbf{2 0 0 0}-\mathbf{2 0 1 6}$ & $\mathbf{3 0 - J u n - 1 6}$ \\
\hline 1 & China & $1,37,85,61,591$ & $72,14,34,547$ & $52.30 \%$ & $3106.40 \%$ & $18,00,000$ \\
\hline 2 & India & $1,26,68,83,598$ & $46,21,24,989$ & $36.50 \%$ & $9142.50 \%$ & $15,70,00,000$ \\
\hline 3 & United States & $32,39,95,528$ & $28,69,42,362$ & $88.60 \%$ & $200.90 \%$ & $20,10,00,000$ \\
\hline 4 & Brazil & $20,60,50,242$ & $13,91,11,185$ & $67.50 \%$ & $2682.20 \%$ & $11,10,00,000$ \\
\hline 5 & Indonesia & $25,83,16,051$ & $13,27,00,000$ & $51.40 \%$ & $6535.00 \%$ & $8,80,00,000$ \\
\hline 6 & Japan & $12,64,64,583$ & $11,51,11,595$ & $91.00 \%$ & $144.50 \%$ & $2,60,00,000$ \\
\hline 7 & Russia & $14,63,58,055$ & $10,31,47,691$ & $70.50 \%$ & $3227.30 \%$ & $1,20,00,000$ \\
\hline 8 & Nigeria & $18,68,79,760$ & $9,72,10,000$ & $52.00 \%$ & $48505.00 \%$ & $1,60,00,000$ \\
\hline 9 & Germany & $8,07,22,792$ & $7,17,27,551$ & $88.90 \%$ & $198.90 \%$ & $3,10,00,000$ \\
\hline 10 & Mexico & $12,31,66,749$ & $6,90,00,000$ & $56.00 \%$ & $2443.90 \%$ & $6,90,00,000$ \\
\hline
\end{tabular}

Source: http://www.internetworldstats.com/top20.htm ${ }^{11}$

\section{Teledensity Divide}

The important reason for the constant gap between rural and urban areas in a country is telecommunications infrastructure gap, which results in the information gap between the rural and urban areas. Even though there is an increase in the rural teledensity, the difference between the urban teledensity and rural teledensity exists consistently. Thus the table below indicates the differences.

Table2. Rural Teledensity

\begin{tabular}{|c|c|}
\hline Period & Rural Teledensity \\
\hline $2009-2010$ & 24.29 \\
\hline $2010-2011$ & 33.79 \\
\hline $2011-2012$ & 39.22 \\
\hline $2012-2013$ & 41.02 \\
\hline $2013-2014$ & 43.96 \\
\hline $2014-2015$ & 48.37 \\
\hline $2015-2016\left(9^{\text {th }}\right.$ December 2016$)$ & 51.24 \\
\hline
\end{tabular}

Source: Telecom Regulatory Authority of India ${ }^{12}$

\footnotetext{
${ }^{11}$ http://www.internetworldstats.com/top20.htm

${ }^{12} \mathrm{http}: / /$ www.trai.gov.in/about-us/annual-reports
} 
According to the above table 2 the telecom sector during the period 2015-2016 saw an increase in rural teledensity to 51.24 from 24.29 during the period of 2009-2010 while the urban teledensity too increased from 119.77 in the period 2009-2010 to 156.24 for the period 2015-2016.

\section{INTERNET DIVIDE}

In India, Internet came in the early 1990's, Videsh Sanchar Nigam Limited (VSNL) a first Dial up connection was introduced in India in six cities in 1995. Internet service providers were given lot of opportunities by National Telecom Policy 1999 for many small and large Internet service providers, which resulted in improvement of services and decline in price.

Table3. Internet Penetration in India

\begin{tabular}{|c|c|c|c|}
\hline YEAR & Users & Population & Penetration in percentage \\
\hline 1998 & $1,400,000$ & $1,094,870,677$ & $0.10 \%$ \\
\hline 1999 & $2,800,000$ & $1,094,870,677$ & $0.30 \%$ \\
\hline 2000 & $5,500,000$ & $1,094,870,677$ & $0.50 \%$ \\
\hline 2001 & $7,000,000$ & $1,094,870,677$ & $0.70 \%$ \\
\hline 2002 & $16,500,000$ & $1,094,870,677$ & $1.60 \%$ \\
\hline 2003 & $22,500,000$ & $1,094,870,677$ & $2.10 \%$ \\
\hline 2004 & $39,200,000$ & $1,094,870,677$ & $3.60 \%$ \\
\hline 2005 & $50,600,000$ & $1,112,225,812$ & $4.50 \%$ \\
\hline 2006 & $40,000,000$ & $1,112,225,812$ & $3.60 \%$ \\
\hline 2007 & $42,000,000$ & $1,129,667,528$ & $3.70 \%$ \\
\hline 2009 & $81,000,000$ & $1,156,897,766$ & $7.00 \%$ \\
\hline 2010 & $100,000,000$ & $1,173,108,018$ & $8.50 \%$ \\
\hline 2012 & $137,000,000$ & $1,205,073,612$ & $11.40 \%$ \\
\hline 2015 & $375,000,000$ & $1,251,695,584$ & $30.00 \%$ \\
\hline 2016 & $462,124,989$ & $1,266,883,598$ & $36.50 \%$ \\
\hline
\end{tabular}

Source: www.internetworldstats.com/asia/ ${ }^{13}$

According to the above table 3 Internet penetrations in India has gradually increased from $10 \%$ during the period 1998 to $36.50 \%$ in the period 2016 .

\section{Internet Usage Picks Up In Rural India}

A Boston Consulting Group study says that at present 120 million Indian living is connected to Internet and by 2020; about 315 million Indians living in rural areas will be connected to the Internet. That's about $36 \%$ of the country's total online population.

Table4. Internet Usage Picks Up In Rural India

\begin{tabular}{|c|c|c|c|c|c|c|c|c|c|}
\hline Ict Diffusion & \multicolumn{3}{|c|}{ Segment Size } & \multicolumn{2}{c|}{ Internet Penetration } & \multicolumn{2}{c|}{ Number Of Year Online } \\
\hline Age & $\begin{array}{c}\text { Unemploy } \\
\text { ment }\end{array}$ & $\begin{array}{c}\text { Less } \\
\text { Affluent }\end{array}$ & $\begin{array}{c}\text { Affluen } \\
\text { t }\end{array}$ & $\begin{array}{c}\text { Unemploy } \\
\text { ment }\end{array}$ & $\begin{array}{c}\text { Less } \\
\text { Affluent }\end{array}$ & $\begin{array}{c}\text { Affluen } \\
\text { t }\end{array}$ & $\begin{array}{c}\text { Unemploy } \\
\text { ment }\end{array}$ & $\begin{array}{c}\text { Less } \\
\text { Affluent }\end{array}$ & $\begin{array}{c}\text { Afflue } \\
\text { nt }\end{array}$ \\
\hline $18-30$ YRS & $36 \%$ & $8 \%$ & $19 \%$ & $9 \%$ & $33 \%$ & $30 \%$ & $<1$ & $1-2$ & $>2$ \\
\hline $30-40$ YRS & & & & $15 \%$ & $16 \%$ & & & $<1$ & \\
\hline $40-50$ YRS & $23 \%$ & & $1 \%$ & & & & & & \\
\hline
\end{tabular}

Source: http://www.livemint.com/Consumer/QgM23BLpCo4ovHxA0jpOGM/Rural-India-getting-online-fasterBCG-report.html ${ }^{14}$

The above table 4 says about $36 \%$ of the country's total online population. Currently Boston Consulting Group titled "The Rising Connected Consumer in Rural India" study noted that $70 \%$ of the Internet users living in rural areas.

\footnotetext{
${ }^{13} \mathrm{http}: / / \mathrm{www}$. internetworldstats.com/asia/in.htm

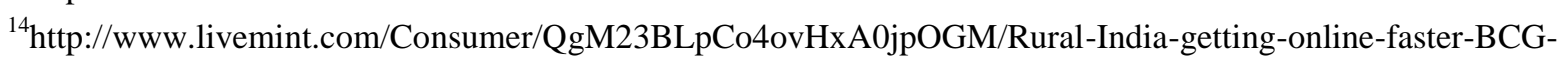
report.html
} 


\section{STATE-Wise ICt Diffusion}

Table5. State-Wise ICT Diffusion

\begin{tabular}{|c|c|}
\hline States & Over all Teledensity(As on sep, 2016) \\
\hline Andhra Pradesh & 86.12 \\
\hline Assam & 61.22 \\
\hline Bihar & 55.52 \\
\hline Gujarat & 101.12 \\
\hline Haryana & 81.55 \\
\hline HP & 133.05 \\
\hline J\&K & 77.67 \\
\hline Karnataka & 103.42 \\
\hline Kerala & 105.23 \\
\hline MP & 61.09 \\
\hline Maharastra & 99.06 \\
\hline Odisha & 73.42 \\
\hline Punjab & 110.34 \\
\hline Rajasthan & 84.21 \\
\hline Tamilnadu & 118.86 \\
\hline UP & 66.81 \\
\hline West Bengal & 82.74 \\
\hline Delhi & 226.94 \\
\hline
\end{tabular}

Source: Teledensity tray 2016PDF

According to the above table 5 it is evident that the ICT diffusion level is more in the other states except Assam, Bihar, Madhya Pradesh and Uttar Pradesh. Therefore the diffusion of telecommunication is more in comparison to the diffusion of Internet and computers.

\section{RURAL INTERNET USERS}

According to the India's census report 2011, of the 121 crore Indian population, 83.3 crore live in rural areas while 37.7 crore stay in urban areas. Nearly $70 \%$ of the country's population lives in rural areas. The below table 6 shows the population of India(Rural and Urban) in crore.

Table6. Population (in Crore)

\begin{tabular}{|c|c|}
\hline Country \& Types & $\mathbf{2 0 1 1}$ \\
\hline India & 121.0 \\
\hline Rural & 83.3 \\
\hline Urban & 37.7 \\
\hline
\end{tabular}

Source: http://www.thehindu.com/news/national/About-70-per-cent-Indians-live-in-rural-areas-Census-report/ article13744351.ece ${ }^{15}$

Until recently the Internet User in India is shifting rapidly with rural India progressively more getting hooked to the Internet since nearly $2 / 3$ rd of India's population live in rural areas, $2 / 3 \mathrm{rd}$ of India's Internet users resides in urban areas. As per an IAMAI and IMRB research, there has been a $93 \%$ year on year rise in rural mobile Internet users. However, in spite of recent growth, data market in the rural areas continues to remain largely untapped with only $13 \%$ Internet penetration, compared to $58 \%$ urban Internet penetration. As Internet penetration in rural India increases, the next wave of growth will be driven rise of rural data customers, whose first data experience will be through Smart phones. This segment will contribute to $70 \%$ of incremental customer case over the next two years. ${ }^{16}$

\section{InITIATIVES Of BRIDGING The Digital Divide In RURAL India}

\subsection{TDIL Project}

Technology Development for Indian Languages (TDIL) Programme was initiated by the Ministry of Electronics and Information Technology; Govt. of India in 1991 has the key objective of emerging

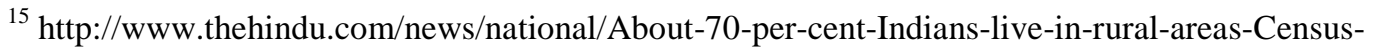
report/article13744351.ece

${ }^{16} \mathrm{http}$ ://telecom.economictimes.indiatimes.com/tele-talk/mobile-internet-driving-digital-rural-india/1807
} 
Information Processing Tools and Techniques to enable human-machine interaction without language barrier; creating and accessing multilingual knowledge resources; and integrating them to develop innovative user products and services. ${ }^{17}$

\subsection{Bhoomi Project}

Bhoomi project is considered to be the flagship of Karnataka state government. The project was inaugurated in the year 2000. This project has earned the international funding agencies and good will of any people. Under this project, the entire manual RTCs that prevailed at the time of data entry were digitized and made available to the citizen through Kiosk Centres. Bhoomi project is considered as self-sustained project ${ }^{18}$

\subsection{Gyanadoot Project}

Gyanadoot project is an Internet in Dhar district in January 2000 connecting rural cyber cafes to the needs of masses and is considered as the mass based Information Technology revolution. The computers have been established in Gram Panchayats. They have been called Soochanalayas. Commencing the Soochanalaya, user-charge based services are given to the masses and at the same time the information technology related developmental requirements of government departments and Panchayats are met free of cost. This Intranet has been named Gyandoot. These kinds of projects demonstrate the rural demonstrate the rural consumers can and will benefit from connectivity. This facilitate in bridging the digital divide. ${ }^{19}$

\subsection{Friends Project}

FRIENDS are the acronym for Fast Reliable Instant Efficient Network for Disbursement of Services. It is a single window 'no queue' integrated remittance Centre, where the citizens pay all taxes and other dues to the Government under one roof at no extra cost. An ongoing project of KSITM, FRIENDS is now operational in all 14 districts of Kerala. ${ }^{20}$

\subsection{Kissan Call Center}

There is an immense challenges faced by the Indian Agriculture. To deliver extension services to the farming community the Department of Agriculture \& Cooperation (DAC), Ministry of Agriculture, Govt. of India launched Kisan Call Centers on January 21, 2004 across the country. Kisan Call Center (KCC) is a revolutionary initiative combination of ICT (Information Communication Technology) and Agriculture technology. This services use backend data support system, which is inbuilt into the overall Management Information System. KCC allows the farmers to have direct discussions with the experts of subjects who are able to analyze the problem effectively and provide the solution directly. In case the operator at the Call Centre is not able to address the farmer's query, instantly the call will be forwarded to agricultural specialists. This would be superior effort made by the Govt. of India to bridge the gap between the right information resource and the user by the phone $^{.2122}$

\subsection{Life Line India}

To create a digital inclusion programme, the Life Lines India service was born of a dream launched in November 2006, which would make a real difference to people who live in rural India by improving their access to technology and information, and narrowing the digital divide for them. The Life Lines India service was launched, as a novel ICT-led help line, under the founder partnership of British Telecom, Cisco Systems and One World. The programme commenced with strategic objectives to:

- To Increase livelihood and income opportunities for rural communities through access to key decisive information

\footnotetext{
${ }^{17}$ http://tdil.mit.gov.in/

${ }^{18} \mathrm{http}$ ://landrecords.karnataka.gov.in/service0/About.aspx

${ }^{19}$ http://www.dhar.nic.in/gyandoot.htm

${ }^{20} \mathrm{http}: / / \mathrm{www}$. itmission.kerala.gov.in/friends.php

${ }^{21}$ http://agritech.tnau.ac.in/kisan/kisan.html

${ }^{22} \mathrm{http} / / / \mathrm{www}$.thebetterindia.com/2304/kisan-call-center-bridging-information-gap/
} 
- Create a sustainable delivery model by concurrently creating a appropriate knowledge base as information exchange takes place through the service

Life Lines India is a mix of internet and telephone technologies - to provide essential and demandbased information, advice and guidance to remote and rural communities in India - through the medium of "voice, in the local language and within 24 hours." The service today has cumulatively covered. ${ }^{23}$

\subsection{Digital India}

Digital India is the Government of India launched a campaign on 1 July 2015 by Prime Minister NarendraModi "Digital India is our dream for the nation. When I say Digital India it is not meant for the rich but for those who are poor". The inventiveness includes plans to connect rural areas with high-speed Internet networks. Digital India consists of three core components. These include:

- The creation of digital infrastructure

- Delivery of services digitally

- Digital literacy

A part of Digital India, The Digital SakshartaAbhiyan (DISHA) or National Digital Literacy Mission (NDLM) Scheme has been framed to impart IT training to the non-IT literate citizens to become IT literate so as to enable them to actively and effectively participate in the democratic and developmental process and also enhance their livelihood.24 India will soon launch Rs. 1,800 crore (\$265 million) Digital Literacy Mission for 60 million people in rural areas as another initiative to bridge the gulf between those who have access to and can use computers and the internet and those who don't, a top official told by IANS ${ }^{25}$

\section{ConCLuSion}

The development of ICT, its applications are changing the way people learn work and interact. The Diffusion in the ICT leads to the information gap between the people have and have-nots in the rural India. Even though there are initiatives and projects such as Kissan call center, Life Line India, Bhoomi Project, Gyanadoot Project, TDIL Project, Friends Project, Digital India, Digital Literacy Mission taken by the Government of India to bridge the gap (digital divide) the inequality prevails. ICT industry growing fastly in India, the country is increasingly getting divided between the people who have access to technology and those who do not.

The ICT infrastructure in India has penetrated in all traits of country, but a large number of people especially from rural areas do not have abilities to use ICTs in proper way. So the government of India has to provide the maximum benefits to tackle the obstacles such as illiteracy, lack of skills and in infrastructure in the rural areas. Since India's heart lies in its villages, rural library and enriched campaigning programme can play a vital role in bridging the digital divide in rural developments and also in building a well knowledgeable and literate society.

\section{REFERENCES}

\section{E-Journals:}

[1] Baliamoune-Lutz and Mina (2003). An analysis of the determinants and effects of ICT diffusion in developing countries. Information Technology for Development, 151-169.

[2] Wong Poh-Kam (2002). ICT production and diffusion in Asia Digital dividends or digital divide? Information Economics and Policy, 167-187.

[3] Sassia Seifallah and Mohamed Goaieda (2013). Financial development, ICT diffusion and economic growth: Lessons from MENA region. Telecommunications Policy, 252-261.

\footnotetext{
${ }^{23}$ http://lifelines-india.net/lifeline/aboutlifelines

${ }^{24} \mathrm{http}: / /$ ndlm.in/

${ }^{25} \mathrm{http}: / / \mathrm{www} . \mathrm{ndtv} . \mathrm{com} /$ india-news/digital-india-connecting-rural-india-with-mainstream-industry-leaders1426869
} 
[4] Dijk Jan van and Kenneth Hacker (2011). The Digital Divide as a Complex and Dynamic Phenomenon. The Information Society, 315-326.

[5] Chopra Anand (2008). Sustainability Failures of Rural Telecenters: Challenges from the Sustainable Access in Rural India (SARI) Project. Information Technologies \& International Development.

[6] P Nair Prema and Mathiyalagan N (2008). Revamping organizations through ICT rat race at workplace. Mass Communicator, 14-26.

[7] Cecchini Simone and Christopher Scott (2003). Can information and communications technology applications contribute to poverty reduction? Lessons from rural India. Information Technology for Development, 73-84.

[8] Best Michael L and Kumar, Rajendra (2002). Sustainability Failures of Rural Telecenters: Challenges from the Sustainable Access in Rural India (SARI). Information Technologies \& International Development.

[9] Blattman Christopher, Robert Jensen and Raul Roman (2002). Assessing The Need And Potential Of Community Networking For Developing Countries: A Case Study From India.

\section{Websites:}

[10] agritech.tnau.ac.in/kisan/kisan.html

[11] www.dhar.nic.in/gyandoot.htm

[12] www.internetworldstats.com/asia/in.htm

[13] www.internetworldstats.com/top20.htm

[14] www.itmission.kerala.gov.in/friends.php

[15] landrecords.karnataka.gov.in/service0/About.aspx

[16] lifelines-india.net/lifeline/aboutlifelines

[17] www.livemint.com/Consumer/QgM23BLpCo4ovHxA0jpOGM/Rural-India-getting-online-faster-BCGreport.html

[18] ndlm.in/

[19] www.ndtv.com/india-news/digital-india-connecting-rural-india-with-mainstream-industry-leaders1426869

[20] www.oecd.org/sti/ieconomy/ictdiffusiontobusinessnationalpeerreviews.htm

[21] tdil.mit.gov.in/

[22] telecom.economictimes.indiatimes.com/tele-talk/mobile-internet-driving-digital-rural-india/1807

[23] www.thebetterindia.com/2304/kisan-call-center-bridging-information-gap/

[24] www.thehindu.com/news/national/About-70-per-cent-Indians-live-in-rural-areas-Census report/article13744351.ece

[25] www.trai.gov.in/about-us/annual-reports 